Marquette University

e-Publications@Marquette

English Faculty Research and Publications

English Department

4-1-2011

\title{
Amitav Ghosh and the Aesthetic Turn in Postcolonial Studies
}

John Su

Marquette University, john.su@marquette.edu

Published version. Journal of Modern Literature, Vol. 34, No. 3 (Spring, 2011): 65-86. DOI. (C) 2011 Indiana University Press. Used with permission. 


\title{
Amitav Ghosh and the Aesthetic Turn in Postcolonial Studies
}

\author{
John J. Su
}

Marquette University

This essay explores the "aesthetic turn" in postcolonial studies in light of the literary works of Indo-Burmese author Amitav Ghosh. While a renewed interest in aesthetic theories is apparent throughout the humanities in the past decade, it is particularly striking in postcolonial studies, where it holds out the possibility of blending the materialist/ bistoricist and culturalist/textualist strands of postcolonial scholarship. Recent studies by Deepika Bahri, Nicholas Brown, Ato Quayson and others have been enormously promising; this essay argues for bringing their Frankfurt School-influenced aesthetic theories into conversation with other theories of aesthetics. Particular attention in this essay is given to the quasi-Kantian conception of beauty that emerges in Ghosh's The Glass Palace (2001), which seeks to balance the desire for universal norms with the need to respect cultural differences.

Keywords: aesthetics / postcolonial theory / utopia / Amitav Ghosh / Theodor Adorno

W

hile a renewed interest in aesthetics is apparent throughout the humanities, it is particularly striking in postcolonial studies. As recently as 2003, Deepika Bahri lamented what she saw as a "remarkable lack of a sufficiently developed critical framework for addressing "the aesthetic dimension' (in Herbert Marcuse's words) of postcolonial literature” (1). For decades, the term aesthetics - when it appeared in scholarly discussions at all — signaled little more than opprobrium. ${ }^{1}$ Since the publication of Bahri's Native Intelligence: Aesthetics, Politics, and Postcolonial Literature, however, aesthetics has become a central preoccupation among postcolonial scholars, and books including Nicholas Brown's Utopian Generations (2005) and Ato Quayson's Aesthetic Nervousness (2007) signal a potentially significant shift in the field. Postcolonial studies first acquired disciplinary legitimacy, according to Robert Young, by devaluing the "aesthetic qualities" of a work and focusing instead on its depiction of "representative minority experience" (7). ${ }^{2}$ So, a reversal is not without significant risk. Modern notions of aesthetics, as they emerged in eighteenth-century European thought, were intimately linked to the intellectual and ideological justifications for 
worldwide colonial expansion. Focusing on the aesthetics of postcolonial literary texts thus risks denying cultural differences under a universalizing Enlightenment discourse, drawing attention away from political concerns in favor of a rarefied formalism and realigning the field with its most conservative forebears including Matthew Arnold, Edmund Burke and T. S. Eliot, for whom aesthetics involved an elitist notion of "high culture" that devalued artistic works produced from Britain's colonies.

Bahri's intervention in Native Intelligence has been so timely because it proposes a compromise between the two dominant strands of postcolonial scholarship, which Laura Chrisman and others have characterized as materialist/ historicist and culturalist/textualist (see, for example, Chrisman 1). The Frankfurt School critical theory that provides the framework for Native Intelligence enables Bahri to address concerns by materialist critics that postcolonial theories are inattentive to connections between artistic production and global flows of capital; it also enables her to rationalize the study of elite, metropolitan texts that have been widely consumed by Western audiences and crowned with Western literary prizes. The negative utopianism for which she argues provides a compelling alternative to the cosmopolitan migrant utopianism endorsed previously by Homi Bhabha and Iain Chambers, and her readings of Salman Rushdie, Rohinton Mistry and Arundhati Roy usefully situate their works in a critical though inseparable relation to the material histories surrounding their production.

The risk in promoting aesthetic theories identified with Frankfurt School thinkers is that they might come to dominate how aesthetic questions are read across the board. The very powerful readings produced by Bahri and Brown, for example, presuppose an unnecessarily extreme opposition between so-called positive and negative utopias inherited from Frankfurt School thinking. According to these readings, utopian thinking is either positive in the sense of attempting to represent the concrete features of an alternative world directly, or negative in the sense of gesturing toward an alternative world that can be intimated but neither represented nor known at the present moment. The preoccupation with negative utopias by Theodor Adorno, Walter Benjamin and Herbert Marcuse is founded on assumptions about the worldwide dominance and stability of capitalism and its apparently unlimited capacity to appropriate utopian representations within a system that commodifies all features of existence. Bahri herself recognizes that Frankfurt School theorists failed to account for the importance of the unique histories of anti-colonial resistance. Yet she follows Adorno in characterizing positive utopian thinking as mere "pseudo-reflection" (Bahri 9), arguing that what is required is an insistent interrogation of the very idea that we can know what utopia might look like. Brown similarly dismisses positive utopias as politically useless and reactionary in that they simply rearticulate current social life in futuristic forms (22-23). But even among the most famous authors emerging during the era of decolonization, the novel provides the opportunity to articulate utopian aspirations in positive terms. Readers of Wole Soyinka's Season of Anomy (1973), Ngũgĩ wa Thiong'o's Devil on the Cross (1980) and Chinua Achebe's 
Anthills of the Savannah (1987) can find very specific descriptions of idealized communities - their ethnic makeup, their economic system, their governance, their attitude toward religion and the supernatural. In the latter two novels, these communities are rapidly eliminated by forces bent on preserving a neo-imperialist form of capitalism. But their brief presence suggests that the distinction between positive and negative utopian thinking is not rigid, and the promesse du bonheur to which Adornean negative utopias gesture may in fact be more fully realized when combined with efforts to articulate more precisely the needs that must be addressed, and perhaps even the constitutive features of a more utopian world.

My project complements the recent aesthetic turn in postcolonial studies by exploring how aesthetic categories central to Enlightenment reason are reclaimed and redeployed within postcolonial contexts. Particularly within Southeast Asia, Dipesh Chakrabarty argues, European thought has been indispensable, though inadequate, to think through the experiences of political modernity in nonWestern nations. ${ }^{3}$ Given the centrality of the aesthetic to the formation of modern nation states in Western Europe and the dominant ideological forms of class society appropriate to them, the importance of sentiments, affections and bodily habits - the so-called aesthetic realm — to forms of postcolonial reasoning needs to be explored.

Taking my lead from Simon Gikandi's claim that European conceptions of the aesthetic were often valued most by individuals from populations that were deemed incapable of aesthetic experience, I would like to pay particular attention to constructions of beauty in postcolonial literary texts. My focus is guided in part by the desire to bring Frankfurt School nonidentitarian aesthetics into conversation with Kantian and hermeneutic schools of thought. The insistent reappearance of beauty in the political philosophy of both Marcuse and Adorno suggests its enduring capacity to motivate anti-imperialist sentiment. Highlighting this point is particularly important because contemporary discussions of their aesthetics often demonstrate a curious aversion to beauty. This absence is ironic given that Marcuse criticizes Marxist aesthetics for rejecting the idea of the beautiful (62) and Adorno devotes three chapters of his Aesthetic Theory to the topic. My focus on beauty is also guided by the sense that the aesthetic has played a crucial role in the constitution of both colonial and anti-colonial thought in ways that have not been fully recognized. The aesthetic has had a mixed career within Western thinking, but it has been crucial to utopian thinking not only among theorists identified with the Frankfurt School. As Terry Eagleton and Geoffrey Galt Harpham suggest, the centrality of the aesthetic to modernity and Enlightenment thinking has to do precisely with its capacity to provide at least a theoretical basis for a utopian society. ${ }^{5}$ Kant argued that every judgment of taste presupposes a sensus communis - a sense that judgments can and must have universal validity (\$20-22). By making beauty an object of consensus, Kant models in aesthetic judgment a process of intersubjective communication that, in the words of Tobin Siebers, makes "aesthetics indispensable to a democratic conception of political judgment" and the conception of utopia itself (32). ${ }^{6}$ 
In this essay, I will explore the engagement with aesthetics undertaken by the Indo-Burmese author Amitav Ghosh. Since his first novel, The Circle of Reason (1986), Ghosh has explored the dehumanizing effects of capitalism and imperialism, and his work has been contrasted favorably with Rushdie's by Marxian scholars. ${ }^{7}$ Yet his repeated declarations of his aesthetic debt to V. S. Naipaul-who perhaps more than any other postcolonial author has been vilified for his putative sympathies with Empire - highlight his complex and evolving attitude toward the aesthetic. ${ }^{8}$ For Ghosh, questions of aesthetics are intimately related to questions of utopia, and he has consistently portrayed in positive terms his notion of a more egalitarian society. As was the case with Achebe, Soyinka and Ngũgĩ, utopias in Ghosh's works tend to be destroyed by the forces against which they respond. Yet his novels refuse to characterize them as failed projects, and they play a crucial role in his efforts to identify in the notion of beauty the possibility of communicating experience while respecting cultural differences.

\section{AESTHETICS SPACES AND IDENTIFICATION}

While Ghosh has portrayed utopian communities since The Circle of Reason, the connection between aesthetics and utopian thinking is most fully developed in his fifth major work, The Glass Palace (2000). Ghosh himself has described this sprawling, multigenerational narrative as both a "family memoir" and a "history of the Indian diaspora in Southeast Asia" (Aldama 87, 89). The novel traces the tumultuous history of modern Burma (officially known as Myanmar since 1989) primarily through the families of Rajkumar (an amoral Bengali entrepreneur who emigrates to Burma at an early age) and Uma Dey (an Indian independence activist). Their lives are shaped by violence: the 1885 deposition of the Burmese royal family by the British, two World Wars and the 1962 military coup. Yet The Glass Palace provocatively portrays its characters seeking out spaces associated with beauty and art, particularly in moments of political crisis. In the first pages of the novel, eleven-year-old Rajkumar dreams of witnessing the marvels reputed to be in the Glass Palace, the residence of royal family. His opportunity arrives after the British military sack the palace and crowds of Burmese are looting its contents. Rajkumar's second son, Dinu, becomes enraptured decades later by the natural beauty of the Malayan countryside beyond his family's rubber plantation. He becomes increasingly absorbed with photographing his surroundings as the Japanese military machine moves across Southeast Asia. Late in the novel, an elderly Dinu holds weekly discussions about aesthetics among students, artists and dissidents in his photographic studio, which he names the Glass Palace. These discussions provide a space to speak freely for people who have been educated by the military regime of Myanmar to accept what Dinu calls "the habit of obedience" (438). Answering young revolutionaries who consider aesthetic matters irrelevant to politics, Dinu declares that "I quoted Weston... Weston reflecting on Trotsky ... that new and revolutionary art forms may awaken the people or disturb their complacency or challenge old ideals with constructive processes of change" (439; ellipses in original). 
The unambiguously positive portrait of Dinu's circle runs counter to Adorno's nonidentitarian aesthetics, which suggests that artworks cannot represent a more egalitarian world disentangled from capitalist exploitation. ${ }^{9}$ Works of art participate in the reification of human relations to the extent that they impose an aesthetic form onto the formless diversity of life. Thus, Adorno proposes a kind of existential corollary to the familiar point that capitalism depends on mystifying the means of production: language necessarily involves an act of violence whereby the object of representation is defined exclusively in terms of the subject's categories of understanding. Positive utopian thinking, then, is not simply wrongheaded but dangerous in that it promotes such violence; art "achieves an unreal reconciliation at the price of real reconciliation" (Aesthetic Theory 52). Any consolation that art might provide renders everyday life that much less intolerable, and, in so doing, reduces the possibility that people will risk actions necessary to change their economic and social conditions. According to this line of thinking, then, the portrayal of Dinu's circle fails to recognize how efforts to envision alternatives from the present vantage point only contribute to the increasingly totalizing grip of capital by providing a melancholic consolation: utopia exists in art, if not in life. ${ }^{10}$

The utopian portrait of Dinu's Glass Palace is intriguing given that Ghosh shares with Frankfurt School thinkers some fairly basic assumptions about the political and economic conditions governing the globe. In a 1995 essay entitled "The Fundamentalist Challenge," he declares:

Today, for the first time in history, a single ideal commands something close to absolute hegemony in the world: the notion that human existence must be permanently and irredeemably subordinated to the functioning of the impersonal mechanisms of a global marketplace. (Incendiary Circumstances 136)

The worldwide hegemony of capitalism is perhaps the most fundamental axiom of Adorno's thought, and his entire aesthetic theory can be read as a response to this first principle. Nonidentitarian thinking emerges from the sense that artistic representations are incorporated within a capitalist system committed to perpetuating itself through commodifying all elements of human existence. Ghosh is also clearly sympathetic to Adorno's more existential critique of language's inadequacy to represent its objects. In the preface to his book of essays Incendiary Circumstances (2005), for example, Ghosh echoes the challenge issued by nonidentitarian thinking when he asks: "is it possible to write about situations of violence without allowing your work to become complicit with the subject?" (x). In other words, can the artist represent his or her subject matter without appropriating or commodifying it?

Ghosh's decision to portray the dissident leader Daw Aung San Suu Kyi as the political inspiration for Dinu's Glass Palace, then, seems puzzling, as does his description of Aung San Suu Kyi herself near the end of the novel. Indeed, the novel explicitly portrays her as an aesthetic figure in at least two prominent senses of the term. First, she is identified as a figure of beauty. "She was beautiful almost 
beyond belief," notes Dinu's visiting niece, Jaya (466). Second, she is identified with the notion that people must safeguard spheres of existence outside of politics. She is the only leader Dinu has ever believed in, not because of her tactical skills, integrity or success:

she's the only one who seems to understand what the place of politics is ... what it ought to be ... that while misrule and tyranny must be resisted, so too must politics itself . . that it cannot be allowed to cannibalize all of life, all of existence. To me this is the most terrible indignity of our condition - not just in Burma but in many other places too ... that politics has invaded everything, spared nothing ... religion, art, family. ... (467; ellipses in original)

This portrait invites readers to engage in identification with precisely the kind of literary character of whom Adorno is contemptuous. From Adorno's perspective, the portrayals of Dinu's Glass Palace and Aung San Suu Kyi would confirm the inevitability of current conditions, limiting readers' capacity to sense the possibility of fundamentally different alternatives. The novel provides, in other words, consolation for the world as it is, rather than an intimation of the world as it could be.

Both Ghosh and Adorno locate in beauty a kind of utopian promise that an alternative to the present repressive system must exist; however, their different conceptions of beauty highlight their different understandings of utopian thinking. Adorno reverses the tendency of Western aesthetics since Hegel to prioritize artistic over natural beauty, suggesting instead that art has value only insofar as it is an imitation of natural beauty. Adorno's reversal is motivated neither by a romantic sensibility that infuses nature with some spiritual dimension nor by an ecological consciousness that evaluates human development in terms of sustainable economic practices. Rather, natural beauty is characterized by an "essential indeterminateness" (70) because nature itself represents a "plenipotentiary of immediacy" (62). The term natural beauty functions as a placeholder to describe those things in the world that have yet to be appropriated by capitalism, and the category is important because it provides the basis for an allegory of the limits of bourgeois society's capacity to extinguish alternatives to itself. "Natural beauty is the trace of the nonidentical in things under the spell of universal identity," Adorno declares (73). Put another way, nature functions as the repository of the "nonexistent" that Adorno identifies as the basis of all genuine utopian thinking. The existence of natural beauty is utopian not because it provides a sign of the more humane natural world or an image of a reconciled Nature and humanity, as it did for Kant, but because it indicates that capitalism can never entirely appropriate all features of existence.

Ghosh's notion of beauty, at least as it is associated with Aung San Suu Kyi, resonates more with Kantian than with Adornean aesthetics. Kant famously defined beauty as that which defies an observer's rules, laws and other pre-given concepts and categories of understanding. ${ }^{11}$ Jaya finds herself absorbed by Aung San Suu Kyi's beauty precisely because the latter defies everything she expected 
to see in Myanmar. Aung San Suu Kyi's speech was "completely unlike anything she'd ever heard" (466), and her laughter infects the large crowd that has risked the wrath of military intelligence to see her. She is "beautiful," in other words, because she physically embodies the hopes of the Burmese people to produce an alternative political regime in their lifetimes. When Jaya finds herself thinking that "it was impossible to behold this woman and not be half in love" (467), she models Kantian judgment in positing a sensus communis, a universal validity to her judgment of taste. She makes no attempt to force her judgment on others, but she does feel the need to engage with those around her to validate it. The novel reinforces Jaya's aesthetic judgment by having Dinu declare that Aung San Suu Kyi defies efforts even by the military regime to categorize her. Noting that the government has labeled her an imperialist, Dinu declares that such efforts only highlight their illegitimacy.

A similar ideal of beauty functions as the basis for the group that meets at his Glass Palace. The gatherings at Dinu's photographic studio are entirely voluntary and unplanned, and Dinu himself resists enforcing his standard of taste as the model. The novel emphasizes aesthetic and cultural differences among participants, differences that are never entirely dissolved, although the participants typically choose to keep returning. Here again, something like Kant's sensus communis emerges, where participants are allowed to defer temporarily their commitments to the outside world in pursuit of a disinterested discussion of aesthetic values. The model of debate and exchange that the gatherings embody provides a symbolic representation of a community learning to balance the contradictory impulses of freedom and social responsibility. ${ }^{12}$

In terms of the formal dimensions of the novel, the narrative exemplifies the notion of beauty its characters describe by deliberately eliding generic expectations, blending fiction and nonfiction. ${ }^{13}$ Ghosh declares in the "Author's Notes" that end The Glass Palace that he is creating a "parallel, wholly fictional world" (471), yet the novel repeatedly emphasizes its basis in historical fact. The narrative is prefaced with a map of Southeast Asia, locating the work in time (the map notes that it presents "Territorial Boundaries ca. 1945") and place (the map presents an image of where the original Glass Palace was located). The "Author's Notes" identify an exhaustive list of sources, and Ghosh states that he read "hundreds of books, memoirs, travelogues, gazetteers, articles and notebooks, published and unpublished" in preparation for writing (471); additionally, he provides an extensive list of people interviewed and locations visited. Even his concession that he presents a fictional world is qualified by his declaration that he has deliberately fictionalized certain events and omitted certain sources out of "fear of reprisals against those concerned" by agents of Myanmar's military regime (473). The apparent fictionality of the text thus appears to be a rhetorical necessity rather than an indication of creative autonomy. The formal features of the novel encourage readers to downplay the artifice inherent in having characters articulate and dispute conceptions of beauty. Whereas Adorno advocated an art whose formal features stand in tension with its content, Ghosh uses the formal features of The 
Glass Palace to encourage readers to view its content as a gloss on current political events. Or, put another way, for Adorno, aesthetic form emphasizes that utopian alternatives can never be entirely eradicated, and the experience of beauty emerges from a kind of contentless form; for Ghosh, in contrast, aesthetic form emphasizes the permeability between lived and imagined worlds, and the experience of beauty emerges from a sense that alternatives are always apparent in everyday life.

Ghosh's insistence on the permeability between lived and imagined worlds is motivated by a concern that memories of life under repressive regimes are often lost. In the "Authors's Notes," Ghosh emphasizes that he was "forced" to create a fictional world because so many of the original memories were fading or censored (471). Fiction becomes a necessary means of preserving and communicating fragmentary experiences, and the representation of fictional characters such as Dinu underscores the continuing inability of the military regime to direct or restrict the lives of its citizens. Ghosh never denies that his fictionalization of life in contemporary Myanmar risks simplifying or sentimentalizing political dissent, repackaging it for consumption by first-world audiences. But his more basic concern that such experiences might be lost altogether to the outside world and other dissidents outweighs concerns about the violence perpetuated by literary representations. The quasi-existential character of Adorno's wholesale critique of representation emerges from a particular historical vantage point from which capitalism appeared to have an almost uniform world dominance. The relative isolation of Myanmar from the market system and the continued capacity of dissidents including Aung San Suu Kyi to challenge the regime, in contrast, provide the grounds for Ghosh to perceive a far more uneven world landscape, in which artists could "reimagine the space[s] for articulate, humane, and creative dissent" that are at least partially beyond the control of state power (Incendiary Circumstances 137). ${ }^{14}$ Such a possibility animates not only Ghosh's descriptions of Dinu's Glass Palace but also the generic form of the novel. Ghosh's declaration that The Glass Palace is a "family memoir" rather than a more explicitly politically engaged literary form such as social realism or protest literature recalls Dinu's concern that politics in Myanmar threatens to "cannibalize all of life." While the chapters leading up to the final scene of the novel focus on Dinu's Glass Palace and the visit to Aung San Suu Kyi, the very last scene shifts its emphasis away from the political to the familial. Jaya relates to Dinu her most enduring memory of his father, Rajkumar. The memory concerns not political dissidents or speeches or protests but a moment of quiet domestic happiness, a wryly sweet version of the consummation scene between the novel's two primary families: Jaya describes to Dinu how her son discovered an elderly Uma and Rajkumar naked in bed together and witnessed his first kiss.

My point is not to dismiss the relevance of Adorno's aesthetic theories but rather to suggest that we might benefit from extending Dipesh Chakrabarty's argument for provincializing Europe - that while modernity may indeed represent a dominant world system, it has been experienced historically in such radically different ways that the ontological assumptions underlying modern European political and aesthetic thought may limit how postcolonial literatures can 
be understood. ${ }^{15}$ Ghosh's aesthetics are shaped by a much more heterogeneous, fractured and fluid conception of modernity than Adorno's, and this is reflected in Ghosh's willingness to risk representing utopian communities. ${ }^{16}$ Ghosh is not insensitive to the limited capacity of language to represent experience. As will become apparent later in this essay, Ghosh's insistence on representing beauty and utopian communities comes not despite but because of his sense that Enlightenment thinking has been guided by a desire to appropriate non-European others within a single dominant historical narrative that gives primacy to colonial empires and, more recently, to neocolonial forms of economic exploitation.

\section{UTOPIAS POSITIVE AND NEGATIVE}

The engagement with Kantian aesthetic thinking in Ghosh's work can be traced back to his first novel, The Circle of Reason, in which he highlights the historical connection between aesthetics and instrumental reasoning. Indeed, for Yumna Siddiqi, the central question of the novel is whether its "succession of utopian projects" can utilize an "alternative, nonrepressive rule of reason" (176) that divorces the emancipatory elements of Enlightenment reason from its coercive elements. ${ }^{17}$ Early in the novel, the rural Indian schoolteacher, Rationalist and Pasteur fanatic Balaram declares that empirical reasoning does not belong to the West but is universal. "Science doesn't belong to countries. Reason doesn't belong to any nation," he declares. "They belong to history - to the world" (54). In the small village of Lalpukur, he undertakes schemes to decontaminate residents and refugees alike with carbolic acid and founds The Pasteur School of Reason with its Kantian departments: the Department of Pure Reason and the Department of Practical Reason. The text clearly satirizes his ambitions, but he does provide a model for local villagers to combine education with vocational training that enables them to remain self-sufficient while continuing their studies. Balaram himself understands his utopian project as having an aesthetic quality, describing his plan as "[s]imple and beautiful: knowledge coupled with labour" (109). Similar visions of beauty as the embodiment of a highly organized community underline the utopian thinking of characters for the majority of the novel. When Balaram's nephew and ward, Alu, later envisions his own utopian community, he too sees it as the realization of Pasteur's vision (280). Alu's socialist community bans money because he equates it with impurity. "No money, no dirt will ever again flow freely in the Ras," he declares (281).

The success of both Balaram's Pasteur School of Reason and Alu's Ras signals a simultaneous fascination and discomfort with utopian schemes based on aesthetic ideals. The Circle of Reason does not characterize the aesthetic as inherently coercive: Balaram's and Alu's projects neither fail nor become repressive, but are eradicated by agents of the states in which they reside. Yet the novel demonstrates significant anxieties about the historical outcomes that emerge when aesthetics becomes central to political discourse. The final utopian figure in the novel, Dr. Uma Verma, rejects the notion of utopia built on an aesthetic ideal in favor of a 
kind of syncretism best exemplified by the cremation ceremony she organizes for Alu's companion Kulfi. Dr. Verma's presence in the novel provides a counterpoint not only to the Enlightenment rationalism endorsed earlier by Balaram but also to the socialism of her colleague Dr. Mishra. In the span of twenty pages, she is portrayed as rejecting her father's obsession with books as a longing for order lacking in the world (395); criticizing the socialism of Dr. Mishra as one more orthodoxy (409); and, in the midst of her cobbled together cremation ceremony, declaring that action cannot wait for a more organized or pure world. "Nothing's whole anymore," she says. "If we wait for everything to be right again, we'll wait for ever [sic] while the world falls apart. The only hope is to make do with what we've got" (416-17). ${ }^{18}$

Rereading The Glass Palace through the lens of The Circle of Reason, it becomes apparent that Ghosh takes pains to portray the dystopian potential of communities based on an aestheticized notion of order. Put another way, Ghosh tempers the portrait of the second Glass Palace with the cautionary tale of the first. The Burmese Queen is so insistent on making everyone around her conform to her principles of order and decorum that she punishes anyone who would defy them, killing the King's closest relations and disowning her own children when they fail to live up to her expectations. Indeed, the novel is filled with examples of what Marc Redfield has called the "potentially dehumanizing thrust of aesthetic formalization" (22). Uma Dey's husband - the District Collector in charge of monitoring the Burmese royal family after they have been exiled to a small coastal village in India - provides the clearest allegory of the dark side of aesthetic education. As one of the few Indians to rise to prominence in the Civil Service, Beni Prasad Dey is obsessed with demonstrating his legitimacy, which he sees measured in terms of his mastery of British culture and social mores. His sense that British military and political superiority is couched in an aesthetic superiority becomes apparent in his attitude toward the Burmese royal family. "But what could they possibly know of love, of any of the finer sentiments," he thinks, "these bloodthirsty aristocrats, these semi-illiterates who had never read a book in all their lives, never looked with pleasure upon a painting?" (131). An Arnoldian sensibility is apparent in how he measures their capacity to experience love by their familiarity with Western art forms. In the mind of the Collector, the queen's lack of a proper aesthetic education leads to her monstrous cruelty. Yet his own life, which he deliberately models on an aesthetic ideal, is portrayed as lacking genuine passion or sympathy. On learning that Uma is planning to leave him, he laments: "I used to dream about the kind of marriage I wanted. ... To discover together the world of literature, art: what could be richer, more fulfilling?" (149). In practice, however, life becomes an intolerable obsession with fulfilling proper form and etiquette, and the Collector ridicules his wife on a daily basis for improperly arranging the silver and a myriad of other such failings. Even his suicide by paddling out to sea in an old racing scull left behind by an Englishman seems strikingly formal and cold, without any reflection on the costs to Uma. 
The dark side of aesthetic appreciation identified in Ghosh's fiction has historically nagged efforts to extract a political philosophy out of Kant's Critique of Judgment: to balance the need to respect and preserve difference with the longing to retain the possibility of universality. Kant's aesthetic theory has intrigued interlocutors from Schiller to Hannah Arendt and Jean-François Lyotard because of its assertion that universally compelling norms can emerge from the interactions between free and independent subjects. Or, as Tobin Siebers puts it, "Beauty is a vision of a plural universe in which self and other necessarily meet - a universe in which one must contend with others and other logics, ... with purposes beyond our meddling and understanding" (43-44). The aesthetic involves intimately personal affections, sentiments and feelings that are not subsumed by rational cognition or the categories of understanding on which it depends, yet aesthetic judgments draw individuals into dialogue with others. Precisely because an individual feels that his or her judgments should have universal validity he or she is led to share experiences with others. That aesthetic judgments presuppose universal validity or a sensus communis does not necessarily mean that they impose a single, monolithic and universal notion, although this has often been the historical reality. As the debates in Dinu's Glass Palace attest, sharing experiences may not lead to consensus, nor does every effort to communicate experience succeed in overcoming barriers of language and philosophical bias. The potential for dialogue that the aesthetic permits always risks collapsing into the demand for assent (as demonstrated by the District Collector toward Uma), and the notion of consensus on which beauty is based always risks becoming a tool for silencing dissenting voices and projecting a homogeneity and transparency that do not in fact exist.

On the formal level, The Glass Palace emphasizes the conflicting tendencies of the aesthetic by a establishing a series of dialectical oppositions through its characters. Uma Dey's political activism, for example, emerges in explicit contrast to her husband's tendency to impose an aesthetic order on the world around him. Perhaps the most significant opposition in the novel, however, emerges between Uma's nephew Arjun and Dinu. In the latter half of The Glass Palace, Ghosh employs both a positive and negative utopianism, traced in Dinu's and Arjun's narratives respectively. In contrast to the affirmative portrait of Dinu's Glass Palace discussed earlier, the portrayal of Arjun's experiences in the British military demands that readers extrapolate from his errors and intuitions. As one of the first generation of Indian officers serving in the British army, Arjun takes great pride in the traditions and protocols of his unit. Although his nonmilitary friends and family perceive him to be a mercenary or a tool of British imperialism, he sees himself as part of a special fellowship, the "First True Indians" (242). Renouncing the dietary codes and restrictions with which they were raised, the Indian officers proudly consume the ham, beef, alcohol and cigarettes that make up the diet of their English counterparts, pronouncing themselves "the first Indians to be truly free” (242-43). In many respects, Arjun's error repeats the District Collector's: the belief that an aesthetic education could enable the formation of a shared community of taste or a sensus communis, which would in turn provide the basis for 
political and even national solidarity. Although such a belief animated many of Kant's interpreters, Kant himself was careful to avoid addressing the question of whether a sensus communis could be built, or even whether it actually exists. ${ }^{19}$ For Arjun, however, a shared community of taste is produced simply by adopting English values rather than by encouraging an ongoing dialogue among individuals. Despite Arjun's rhetoric, the basis of taste was determined for the Indian officers by the English; the cultural heterogeneity of the Indian officers was subsumed in the name of an aesthetic ideal to which they all assented but did not arrive at by themselves. ${ }^{20}$ As a result, they lose their capacity to communicate with the Indian soldiers under their command. Only after he is wounded does Arjun even recognize his inability to communicate with his batman about personal issues.

Ghosh uses Arjun's narrative to emphasize the interdependence of positive and negative utopian thinking. In the chapter immediately following the description of Dinu's Glass Palace, Dinu describes to Jaya his final meeting with Arjun. The physical proximity of the story, the fact that it is taken out of chronological context and Ghosh's decision to have Dinu himself relate it all encourage readers to view the scene as a gloss on Dinu's efforts to make his Glass Palace into an aesthetic space that is at least partially isolated from everyday life under the military regime of Myanmar. The meeting between Arjun and Dinu occurred some forty years earlier, in the final days of World War II, as the British army was reclaiming Southeast Asia. By this point, Arjun has deserted the British military and joined the Indian National Army, a group that violently resisted British forces. Desperately malnourished and underequipped to continue his guerrilla campaign, Arjun insists to Dinu that his struggle must continue, even though he has long since abandoned hope:

"Did we ever have hope?" he said. "We rebelled against an Empire that has shaped everything in our lives; colored everything in the world as we know it. It is a huge, indelible stain which has tainted all of us. We cannot destroy it without destroying ourselves. And that, I suppose, is where I am. ...” (446)

That Arjun's expression of despair is voiced through Dinu's retelling indicates the novel's ultimate preference for the latter's positive utopianism. At the same time, the concern Arjun raises about the difficulty of escaping internalized biases provides a necessary counterpoint to the model of aesthetic judgment associated with Dinu's Glass Palace. Arjun's despair is shaped by the same assumption that previously led him to become an officer in the British military: the idea that something like a sensus communis actually exists. Hence, even after he changes his political attitudes - and rejects the Empire that was once central to his identity-Arjun does not believe that he can change his own worldview. The possibility of such change is the governing assumption of both Dinu's Glass Palace and Ghosh's novel. The discussions portrayed by The Glass Palace, like the act of reading itself, are meaningful only because aesthetic experiences suggest that human attitudes are always open to revision. Put more starkly, the notion of a sensus communis, for Dinu and Jaya, represents a necessary assumption or starting 
point for dialogue, not a fixed set of values that can be taken for granted nor a homogeneous set of ideals to which individuals should aspire. Indeed, the novel emphasizes that Dinu's own assumptions are profoundly shaken by his conversation with Arjun. Arjun's determination to resist the British despite his despair forces Dinu to reevaluate his earlier condemnation of Arjun: "How does one judge a person who claims to act on behalf of a subordinated people, a country? On what grounds can the truth of such a claim be established or refuted?" (447).

There is, then, a broad allegory to be drawn from Ghosh's writing about the interdependence of Kantian and Adornean aesthetics. If Kantian aesthetics and its potential political implications are to be divorced from the historical violence perpetuated by Enlightenment thinking - as Jonathan Loesberg and others have sought to do - then a rigorous nonidentitarian critique along the lines proposed by Adorno is necessary. ${ }^{21}$ Put another way, the argument made in the last section that negative utopian thinking is insufficient for the needs of many writers outside of Europe and the United States is counterpointed by the argument in this section that positive utopian thinking is unable to divorce itself from its most pernicious tendencies. In The Glass Palace, Ghosh attempts to render both positive and negative utopian thinking within the aesthetic form of the novel, such that the two modes of thinking mutually correct each other. The portrayals of the Burmese Queen, the Collector and Arjun emphasize the inescapable dangers of utopian thinking and emphasize that Dinu's vision of people engaged in disinterested debate is a heuristic rather than a reality. The Glass Palace proposes the conditions under which individuals are invited to engage with each other in ways that respect potentially intractable differences, and Arjun's inability ever to escape from his own biases reminds readers that such conditions are rarely, if ever, met.

\section{THE ENDS OF THE AESTHETIC}

Crucial to Ghosh's effort to balance positive and negative utopian thinking is the portrayal of the uses to which the aesthetic was put by entrepreneurs intent on exploiting the resources of Britain's colonies. The centrality of Enlightenment aesthetic thinking is apparent in the most significant capitalist enterprise in the novel, the Morningside Rubber Estate. This project-born of the partnership between Rajkumar and his mentor Saya John and implemented by Saya's son Matthew and daughter-in-law Elsa - creates vast wealth for the families during World War I, as competing empires desperately need natural resources such as rubber to sustain their war machines. The estate provides profit by exploiting natural resources and human labor, and the novel makes it clear that the discourse of aesthetics is crucial to rationalizing its existence. "It's beautiful, isn't it?" Elsa declares to Rajkumar's wife Dolly as they pass thousands of rubber trees, all aligned geometrically for efficient extraction (172). Dolly herself admires the labor it must have taken to clear the jungle, but is uncomfortable with what she sees: "there was something eerie about its uniformity; about the fact that such sameness could be imposed upon a landscape of such natural exuberance" (172). 
Elsa's narrative is striking for its implicit invocation of the categories of the beautiful and sublime that emerged in Enlightenment thinkers such as Kant and Edmund Burke. Elsa relates how "horrified" she felt when she first came to the area: "The place was beautiful beyond imagining, but it was jungle - dense, towering, tangled, impassable jungle" (172). The jungle becomes an embodiment of the sublime, something whose grandeur exceeds the capacity of the imagination to understand, thereby filling the witness with feelings of horror and pleasure. What capitalism requires, then, according to this narrative, is the domestication of the sublime into the beautiful. The literal imposition of order by destroying and then replanting the trees becomes a metaphorical imposition of a political, social and moral order.

Elsa's husband Matthew similarly understands capitalism to involve the introduction of the aesthetic into non-Western spaces. When the District Collector's widow Uma describes the workers as slaves, Matthew is quick to reinvoke the language of aesthetics. He says: "It's no easy thing to run a plantation, you know. To look at, it's all very green and beautiful-sort of like a forest. But actually it's a vast machine, made of wood and flesh. And at every turn, every little piece of this machine is resisting you, fighting you, waiting for you to give in" (201). The logic here is that the apparent beauty is not natural, but rather the product of human (that is, Western) labor. The language of beauty also enables an interesting slippage, whereby the humanity of the laborers is denied: they are simply a part of the totality of the scene - part of nature - as indicated by his description of the "machine" as "wood and flesh." And the description of this system as a machine further enables him to suggest that everything is a product of his labor, denying any preexisting social order or ecosystem.

The direction the argument takes between Uma and Matthew indicates Ghosh's sense that the discourse of aesthetics inevitably produces a counterdiscourse of resistance. By folding his laborers into an undifferentiated natural world that is rendered beautiful, Matthew inadvertently posits an opposing tendency toward a "sublime" existence that resists the order he brings. His aesthetic discourse enables him to assert that rationality and justice guide his system of administration. But the consequence is that he cannot attribute acts of resistance, insubordination or even laziness on the part of his employees to either his rule or their own agency, because they have no agency as parts of an undifferentiated nature. Thus, resistance becomes a feature of nature itself, and nature in turn becomes a potential metaphor for the inevitability of resistance to capitalism. Uma recognizes this when she asks the question, "What on earth are you going to do if your tappers decide to take a lesson from your trees?" (202).

Ghosh does not evince the predilection for the sublime over the beautiful that has characterized literary theories and continental philosophy over the past several decades. From Hayden White to F. R. Ankersmit to Jean-François Lyotard to Nicholas Brown and Amy J. Elias, the sublime has been characterized as implicitly emancipatory in contrast to a fascist beauty. ${ }^{22}$ Ghosh, however, never undercuts Dinu's or Uma's assertions about beauty. Rather, aesthetic discourses 
are inescapably heterogeneous in the sense that Chakrabarty describes the political-a notion that defies any single effort to conceptualize it. ${ }^{23}$ Whatever the hopes of Schiller and later romantics, the historical emergence of aesthetics as a legitimatory discourse of capitalism presents real limits to its usefulness. ${ }^{24}$ It nonetheless has a certain unruliness and always has the potential to be unhinged from its initial ideological function. As the scene between Uma and Matthew indicates, the discourse of beauty ends up highlighting the inevitability of resistance, despite every measure taken to ensure order. Despite the fact that Matthew has every single rubber tree imported from a reliable clonal seed, the limits of engineering the social and natural world are mapped in the very representations of the natural world provided by Western discourses. In other words, aesthetics is heterogeneous in the sense that it legitimizes and critiques simultaneously. It should be no surprise then that Adorno himself never entirely rejected beauty, despite his over-quoted assertion that "To write poetry after Auschwitz is barbaric" (Prisms 34). With both Adorno and Ghosh, there is nothing inherent in nature that provides a kind of map for utopia or resistance. Rather, it is the idea of nature as an aesthetic phenomenon that makes it a sign of ineradicable utopian aspirations.

Thus, Ghosh provides a response to concerns that the resurging interest in aesthetics in the humanities might signal a return to a formalism isolated from history or another universalizing discourse that takes culturally contingent values as transparent and "natural." The aesthetic itself, as Ghosh makes clear, emerges historically as a crucial feature of modernity and Western efforts to reorganize everything on the planet within a single controllable economic system. The appeal to aesthetics by capitalists like Matthew and later by the dissidents like Dinu may involve an appeal to a notion of beauty that appears ahistorical, but this is the ideological work to which the aesthetic is put rather than anything to do with the aesthetic itself. The focus on a specifically aesthetic community at the end of the novel, in contrast to utopias in Ghosh's earlier works, needs to be read in this context. Dinu's declaration that aesthetic spaces exist outside the realm of politics is analogous to the claim of a nature that continually defies the efforts of estate owners to mold the jungle to their needs.

Whether the unruly discourses of aesthetics have the capacity to serve the specific disciplinary needs of postcolonial scholars is another question. Postcolonial theory emerges out of a specific crisis of legitimacy in the Anglo-American academy in the 1980s. Scholars like Robert Young who insist that it has more revolutionary roots in 1960s independence movements are not incorrect, but the fact that postcolonial theory experiences such a particular boom when and where it does points to the needs of English departments to defend their own existence at time of budget cuts and an anti-intellectual environment promulgated by conservative governments in the United States and Great Britain. Thus, postcolonial theory has always had at least a triple labor: to understand the successes and failures of revolutionary anti-colonial movements to establish viable states after gaining independence; to provide a theoretical lens for understanding the 
emergence and function of literature produced since the late 1950s; and to provide a political ground for scholars to justify their own existence. The third task, which has provided much fodder for critics of the field from Aijaz Ahmad to E. San Juan Jr., does not invalidate the former tasks. As Simon Gikandi notes, people "burdened with the stigma of difference turned to art (and other modern categories) to affirm their universal identity as human beings" (347). The aesthetic, in other words, remains invaluable despite the repeated and by now pro forma deconstruction of universal identity. Chakrabarty's notion of heterogeneity provides only one obvious way of moving beyond the impasse of unqualified affirmation or absolute negation that has haunted so many discussions. Postcolonial studies has been at the forefront of efforts to challenge the universalizing tendencies of modern European thought, and it in turn could benefit from a more thorough investigation of the deliberate refusal to reduce thought to a single set of categories that has been at the heart of modern aesthetic discourses.

\section{Notes}

1. This tendency is apparent even in Graham Huggan's remarkable The Postcolonial Exotic: Marketing the Margins (2001), which argues that aesthetics provides the means for exploiting cultural differences through the production of a notion of the exotic. Exoticism, according to Huggan, is an "aestheticising process through which the cultural other is translated, relayed back through the familiar" (ix). Aesthetics, as understood here, is a mechanism of decontextualizing cultural practices and traditions in order to render them for consumption by metropolitan audiences. Intriguingly, Huggan holds out the possibility that exoticism in postcolonial writing has the potential to "unsettle metropolitan expectations" and to critique "differential relations of power" (ix, $\mathrm{x}$ ), but aesthetics is not understood to play a part.

2. The curious neglect of aesthetics is apparent in many of the seminal works of postcolonial studies. Aesthetics does not even appear in the index of Edward Said's Orientalism or Homi Bhabha's The Location of Culture; in Gayatri Chakravorty Spivak's A Critique of Postcolonial Reason, "aesthetic judgment" and Hegel's "Aesthetics" each receives a single page reference. Yet Spivak opens her work with a critical reading of Kant's Critique of Judgment, which, according to her argument, inaugurates a tradition within Northwestern European thinking of constructing the native informant as "needed and foreclosed" in order to construct Europeans as the universal human norm (6). Said will similarly locate the rise of modern Orientalism in the late eighteenth century, though he makes no explicit connection to the concurrent rise of modern notions of aesthetics. He does indicate that the aesthetic plays a role in the formation of an imperialist tradition, but only in passing, such as when he asks: "What other sorts of intellectual, aesthetic, scholarly, and cultural energies went into the making of an imperialist tradition like the Orientalist one?" (15).

3. Chakrabarty has been criticized for creating a monolithic, worldwide notion of modernity. Partha Chatterjee provides a useful caution in the context of a critique of Benedict Anderson's thesis on nationalism, arguing that the evidence of "anticolonial nationalism" belies a notion that postcolonial nations are necessarily limited to certain "modular" forms already made available to them by Europe. To accept too readily such arguments about nationalism would risk reducing the postcolonial world to "perpetual consumers of modernity" (The Nation and Its Fragments 5).

4. Gikandi argues: "It is this utopian possibility, the dream that the work of art might actually be separated from the slave economy that sustained it, that made the aesthetic central to the slave's attempt to claim the central categories of bourgeois culture, including freedom, morality, and 
subjectivity. It is one of the great ironies of modern culture that the people excluded from the realm of artistic genius and aesthetic judgments were the ones who valued the aesthetic the most" (344).

5. "No concept is more fundamental to modernity than the aesthetic," Harpham argues, "that radiant globe of material objects and attitudes ideally independent of politics, rationality, economics, desire, religion, or ethics" (124). Eagleton similarly argues: "The construction of the modern notion of the aesthetic artefact is thus inseparable from the construction of the dominant ideological forms of modern class-society, and indeed from a whole new form of human subjectivity appropriate to that social order" (3).

6. It is precisely this notion of communicability that is lost in Adorno's thought, as Hans Robert Jauss recognized more than twenty years ago. Jauss argues: "The strength and indispensability of Adorno's aesthetic theory ... has been purchased at the price of a derogation of all communicative functions" (19). For Jauss, the importance Adorno ascribes to negativity in the experience of art does not require surrendering the possibility of what he terms the "communicative identification with a developing social norm and lifestyle" (18), and the literature of courtly love provides him a crucial example. Such literature, Jauss suggests, involves both a negation of ecclesiastical norms governing marriage and an emancipation of forms of communication between the sexes.

7. For R. Radhakrishnan, Ghosh develops a "strategy of polyvocality and heteroglossia that is much more multi-historical than the kind of metropolitan ventriloquism one finds in the works of Salman Rushdie" (61).

8. In an interview with Claire Chambers, for example, Ghosh declares that he owes Naipaul an "enormous, enormous debt" as a pioneering Indian writer, although he "disagree[s] with almost everything that Naipaul says" (Chambers 35).

9. Nonidentitarian aesthetics, like so many Adornean concepts, defies easy definition. In Negative Dialectics, Adorno defines identity "as the correspondence of the thing-in-itself to its concept" (149). What this means in practical terms is less obvious, however, because Adorno's critique of identitarian thinking appears to grow out of several sources. Susan Buck-Morss notes that Adorno was responding to the tradition of German idealism, and specifically to Hegel; she also notes that this definition was apparently a response to Heidegger and Benjamin (see 43-62, 232-33 n.1). Simon Jarvis insists that Adorno's theory is heavily indebted to Marx's theory of commodity fetishism (167). The implication is that capitalism represents an extreme form of an inherent human tendency to render the world comprehensible by means of classifying objects in terms of linguistic categories. In Chapter 3 of her Native Intelligence, Bahri provides an excellent discussion of Adorno in light of postcolonial theory.

10. Adorno emphasized in his final essay that the conscientious artist or intellectual "neither superscribes his conscience nor permits himself to be terrorized into action," recognizing that the refusal to engage in political praxis is itself the most radical form of dissent (qtd. in Said, "Adorno As Lateness Itself" 202).

11. Kant offers his most concise definition of beauty in $\$ 22$ of The Critique ofJudgment: "The beautiful is that which, apart from a concept, is cognized as object of a necessary delight" (85).

12. Tobin Siebers argues for a politics of beauty that develops Kant's argument in The Critique of Judgment that judgments of the beautiful involve not a private feeling but a "public sense" (84). For Siebers, aesthetic judgment thereby provides an analogy for political judgment: "It offers the experience of a free political space, a space of intersubjectivity, in which a multitude of thinking people are dedicated to an open discussion — unbound by previously existing prejudices — and committed to reaching an agreement acceptable to all. Beauty is, in short, politics' idea of utopia, and although it be utopian, a wonderful idea it sometimes is" (48).

13. In interviews, Ghosh has repeatedly emphasized over the years his efforts to blend and mix genres. In an interview with Frederick Luis Aldama, Ghosh declares: "I know that the institutional structure of our world presses us to think of fiction and nonfiction as being absolutely separate.... But I think the techniques one brings to bear upon nonfiction, certainly the techniques I've brought to bear on nonfiction, essentially come from my fiction" (86). Similarly, in conversation with T. Vijay 
Kumar, Ghosh declares: "See, for me the novel is the form that synthesizes all kinds of expression. ... So this is why I write novels, because I think novels can synthesize geology, history, personal relationships, emotion, everything" (103).

14. In "The Fundamentalist Challenge," Ghosh's call for reimagining spaces of "creative dissent" of the kind that Dinu models is motivated not simply by the desire to find an effective response to the market ideal but also by the anxiety that religious extremism will increasingly become the dominant mode of expressing dissent against it (Incendiary Circumstances 137). Religion, in Adorno's Aesthetic Theory, is dismissed as a pathetic and anachronistic fantasy, "those Sunday institutions that provide solace" (2). In this, he follows Marx in seeing religion primarily as a means of shoring up capitalism by providing promises of eternal, if delayed, gratification for submitting to the yoke of this world. Growing up in post-independence India, Ghosh, in contrast, saw firsthand the capacity of religion to provide a powerful source of identity and political mobilization that is frequently not contained by dominant institutions of power, though religious groups certainly maintain strategic alliances with them. Thus, for Ghosh, the question is not whether artworks have the capacity to express dissent or not; as will become more apparent later, dissent is an inevitable byproduct of capitalism itself. The question is rather what form dissent will take. In the absence of aesthetic spaces, Ghosh concludes that "the misdirected and ugly energies of religious extremism will only continue to flourish and grow" (Incendiary Circumstances 137).

15. Chakrabarty argues that modern European political thought has been consistently guided by historicist assumptions that fail to account for the importance of the supernatural and religious beliefs. Chakrabarty argues: "We need to move away from two of the ontological assumptions entailed in secular conceptions of the political and the social. The first is that the human exists in a frame of a single and secular historical time that envelops all other kinds of time. ... The second assumption running through modern European political thought and the social sciences is that the human is ontologically singular, that gods and spirits are in the end 'social facts,' that the social somehow exists prior to them" (15-16).

16. Lambert Zuidervaart provides a compelling case for reading Adorno's approach as a "crucial counterweight" to prevailing assumptions about the social significance of the arts, even while acknowledging that since his death, new social movements, the emergence of postmodernism and transformations in institutions cast significant doubt on some of Adorno's central premises and arguments (5).

17. Siddiqi follows Partha Chatterjee's seminal argument that nationalism is inextricably tied to Enlightenment rationality, hence stressing the importance of exploring the possibility of separating emancipatory from coercive elements of reason. Siddiqi notes that while the novel does present a number of utopian scenarios, they tend to occur outside of the "bounded and closely regulated territory of the nation" (193). By this placement, Ghosh signals the unlikelihood of establishing a noncoercive reason; at best, he can mark the limits of Enlightenment reason and its guarantee of "epistemological transparency" through the character of Alu, whose opaqueness and unknowability continually defy the efforts of other characters or readers to interpret his reasoning.

18. In the midst of a conversation with Dr. Verma, Alu discovers a passage in The Life of Pasteur declaring that germs are an inevitable part of human life, further undercutting the idea of the "pure" aesthetic utopia.

19. Kant declares in $\$ 20$ : "The judgment of taste, therefore, depends on our presupposing the existence of a common sense. (But this is not to be taken to mean some external sense, but the effect arising from the free play of our powers of cognition)" (83). Indeed, Kant's anxiety about the actual existence of such a sense is apparent in the distinction he introduces between sensus communis and "common understanding" (gemeine Verstand). Common sense, he writes, "differs essentially from common understanding, which is also sometimes called common sense (sensus communis): for the judgment of the latter is not one by feeling, but always one by concepts, though usually only in the shape of obscurely represented principles" (82-83). Henry E. Allison's chapter on "The Modality of Taste and the sensus communis" provides a very useful discussion of the difference between the two terms. 
20. In interviews and essays such as "The Diaspora in Indian Culture," Ghosh has argued that the heteroglossia characterizing Indian culture denies the possibility of a unitary or pre-given coherence to national identity (75, 78; see also Gabriel 40, 43 and Kumar 104).

21. Loesberg proposes a return to aesthetics that involves not only redefining concepts such as autonomous form, disinterest and symbolic embodiment, but also revisiting the history of aesthetics itself: "aesthetics was not the companion to Enlightenment ideas about reason and objective justice, but was rather the model prior to reason and objectivity from which the Enlightenment attempted to give those concepts value" (3).

22. Particularly for Hayden White and F. R. Ankersmit, the preference for the sublime over the beautiful represents a key element in the effort to formulate an alternative, non-Kantian historiography. White famously argued that Western historiography emerged out of eighteenth-century aesthetics and its preoccupation with the category of the beautiful, so that historical narratives become preoccupied with form, order and meaningful teleology through which the historian can provide readers with clear and unambiguous reasons for why events occurred as they did. He argues:

For insofar as the disciplinization of history entailed regulation, not only of what could count as a proper object of historical study but also of what could count as a proper representation of that object in a discourse, discipline consisted in subordinating written history to the categories of the "beautiful" suppressing those of the "sublime." (66-67)

23. In other words, Western historical writing has consistently attempted to appropriate or domesticate all events within a narrative framework. Extending White's argument about the discipline of history and its obsession with the category of the beautiful, Ankersmit argues that history is so tied to its Kantian roots that we cannot see an alternative to a transcendental theory of knowledge, what he calls sublime historical experience. For Ankersmit, experiences tend to resist efforts at appropriation by historians. In stark contrast to Kant and much modern and postmodern philosophy, Ankersmit argues that language should not be seen as the principal condition for the possibility of knowledge and meaningful thinking. Ankersmit argues that language is used in order to avoid experience and the fears and terrors it typically provokes (Sublime Historical Experience 11). Theoretically, at least, the point of honoring sublime historical experiences and making them a part of the discipline of history is to dissolve the absolute boundaries between the past and present and thereby to achieve the opposite of appropriation. In Ankersmit's words, representations of the past do not make the alien familiar but actually defamiliarize the familiar, making us strangers to ourselves (History and Tropology 27). For a contrasting viewpoint, see Isobel Armstrong's The Radical Aesthetic. Armstrong argues that the fascination with the sublime, exemplified by Lyotard and Paul de Man, has been a disastrous choice politically: "But the sublime is a discourse of the past. The radical aesthetic cannot return to the point of no return. It must live in the present and the future" (21).

24. Chakrabarty argues that the poetry of Rabindranath Tagore resists the idea that any one understanding of the political is sufficient. Chakrabarty writes: "This, it seems to me, is the heterogeneity in the very constitution of the political that the nationalist in Tagore articulated in proposing to his compatriots that the nationalist eye needed to possess two radically contradictory modes of vision. One was charged with the responsibility to locate the political in historical time; the other created a political that resisted historicization" (178-79).

25. While Eagleton insists that the aesthetic should neither be celebrated nor condemned uncritically, his own conclusions tend to be relatively pessimistic. In the introduction to The Ideology of the Aesthetic, for example, he declares: "If it offers a generous utopian image of reconciliation between men and women at present divided from one another, it also blocks and mystifies the real political movement towards such historical community" (9). 


\section{Works Cited}

Achebe, Chinua. Anthills of the Savannah. 1987. New York: Anchor Books, 1988. Print.

Adorno, Theodor W. Aesthetic Theory. Trans. Robert Hullot-Kentor. Eds. Gretal Adorno and Rolf Tiedemann. 1970. Minneapolis: U of Minnesota P, 1997. Print.

—. Negative Dialectics. Trans. E. B. Ashton. 1966. New York: Seabury, 1973. Print.

—. Prisms. Trans. Samuel and Shierry Weber. Cambridge, MA: MIT Press, 1981. Print.

Ahmad, Aijaz. In Theory: Classes, Nations, Literatures. London: Verso, 1992. Print.

Aldama, Frederick Luis. “An Interview with Amitav Ghosh.” World Literature Today 76.2 (2002): 84-90. Print.

Allison, Henry E. Kant's Theory of Taste: A Reading of the Critique of Aesthetic Judgment. Cambridge: Cambridge UP, 2001. Print.

Ankersmit, F. R. History and Tropology: The Rise and Fall of Metaphor. Berkeley: U of California P, 1994. Print.

. "In Praise of Subjectivity." The Ethics of History. Eds. David Carr, Thomas R. Flynn and Rudolf A. Makkreel. Evanston, IL: Northwestern UP, 2004. 3-27. Print.

- Sublime Historical Experience. Palo Alto, CA: Stanford UP, 2005. Print.

Armstrong, Isobel. The Radical Aesthetic. Oxford: Blackwell, 2000. Print.

Bahri, Deepika. Native Intelligence: Aesthetics, Politics, and Postcolonial Literature. Minneapolis: U of Minnesota P, 2003. Print.

Bhabha, Homi K. The Location of Culture. London: Routledge, 1994. Print.

Brown, Nicholas. Utopian Generations: The Political Horizon of Twentieth-Century Literature. Princeton, NJ: Princeton UP, 2005. Print.

Buck-Morss, Susan. The Origin of Negative Dialectics: Theodor W. Adorno, Walter Benjamin, and the Frankfurt Institute. New York: The Free Press, 1977. Print.

Chakrabarty, Dipesh. Provincializing Europe: Postcolonial Thought and Historical Difference. Princeton, NJ: Princeton UP, 2000. Print.

Chambers, Claire. “The Absolute Essentialness of Conversations': a Discussion with Amitav Ghosh.” Journal of Postcolonial Writing 41.1 (2005): 26-39. Print.

Chambers, Iain. Migrancy, Culture, Identity. London: Routledge, 1994. Print.

Chatterjee, Partha. Nationalist Thought and the Colonial World: A Derivative Discourse? Minneapolis: U of Minnesota P, 1986. Print.

-The Nation and Its Fragments: Colonial and Postcolonial Histories. Princeton, NJ: Princeton UP, 1993. Print.

Chrisman, Laura. Postcolonial Contraventions: Cultural Readings of Race, Imperialism and Transnationalism. Manchester, UK: Manchester UP, 2003. Print.

Eagleton, Terry. The Ideology of the Aesthetic. Oxford: Blackwell, 1990. Print.

Elias, Amy J. Sublime Desire: History and Post-1960s Fiction. Baltimore: Johns Hopkins UP, 2001. Print.

Gabriel, Sharmani Patricia. “The Heteroglossia of Home: Re-'routing' the Boundaries of National Identity in Amitav Ghosh's The Shadow Lines." Journal of Postcolonial Writing 41.1 (2005): 40-53. Print.

Ghosh, Amitav. The Circle of Reason. 1986. New York: Mariner Books, 2005. Print. 
——. "The Diaspora in Indian Culture." Public Culture 2.1 (1989): 73-78. Print.

—. The Glass Palace. 2000. New York: Random House, 2001. Print.

- Incendiary Circumstances: A Chronicle of the Turmoil of Our Times. Boston: Houghton Mifflin, 2005. Print.

Gikandi, Simon. "Race and the Idea of the Aesthetic." Michigan Quarterly Review 40.2 (2001): 318-50. Print.

Harpham, Geoffrey Galt. "Aesthetics and the Fundamentals of Modernity." Aesthetics and Ideology. Ed. George Levine. New Brunswick, NJ: Rutgers UP, 1994. 124-52. Print.

Huggan, Graham. The Postcolonial Exotic: Marketing the Margins. London: Routledge, 2001. Print.

Jarvis, Simon. Adorno: A Critical Introduction. Cambridge: Polity Press, 1998. Print.

Jauss, Hans Robert. Aesthetic Experience and Literary Hermeneutics. Trans. Michael Shaw. Ed. with an Introduction by Wlad Godzich. Minneapolis: U of Minnesota P, 1982. Print.

Kant, Immanuel. The Critique of Judgment. Trans. James Creed Meredith. 1790. Oxford: Clarendon Press, 1952. Print.

Kumar, T. Vijay. “Postcolonial' Describes You As a Negative.” Interventions: International Journal of Postcolonial Studies 9.1 (2007): 99-105. Print.

Loesberg, Jonathan. A Return to Aesthetics: Autonomy, and Difference, and Postmodernism. Palo Alto, CA: Stanford UP, 2005. Print.

Lyotard, Jean-François. The Postmodern Condition: A Report on Knowledge. Trans. Geoff Bennington and Brian Massumi. Foreword by Fredric Jameson. 1979. Minneapolis: U of Minnesota P, 1984. Print.

Marcuse, Herbert. The Aesthetic Dimension: Toward a Critique of Marxist Aesthetics. Boston: Beacon Press, 1978. Print.

Ngũgĩ. Devil on the Cross. 1980. London: Heinemann Educational Books, 1982. Print.

Quayson, Ato. Aesthetic Nervousness: Disability and the Crisis of Representation. New York: Columbia UP, 2007. Print.

Radhakrishnan, R. "Postmodernism and the Rest of the World." The Pre-occupation of Postcolonial Studies. Eds. Fawzia Afzal-Khan and Kalpana Seshadri-Crooks. Durham, NC: Duke UP, 2000. 37-70. Print.

Redfield, Marc. The Politics of Aesthetics: Nationalism, Gender, Romanticism. Palo Alto, CA: Stanford UP, 2003. Print.

Said, Edward W. "Adorno as Lateness Itself." Adorno: A Critical Reader. Eds. Nigel Gibson and Andrew Rubin. Malden: Blackwell, 2002.193-208. Print.

- Orientalism. 1978. New York: Vintage Books, 1979. Print.

San Juan, E., Jr. Beyond Postcolonial Theory. New York: St. Martin’s Press, 1998. Print.

Siddiqi, Yumna. "Police and Postcolonial Rationality in Amitav Ghosh's The Circle of Reason." Cultural Critique 50 (2002): 175-211. Print.

Siebers, Tobin. "Kant and the Politics of Beauty." Philosophy and Literature 22.1 (1998): 31-50. Print.

Soyinka, Wole. Season of Anomy. London: Rex Collins, 1973. Print.

Spivak, Gayatri Chakravorty. A Critique of Postcolonial Reason: Toward a History of the Vanishing Present. Cambridge, MA: Harvard UP, 1999. Print.

White, Hayden. The Content of the Form: Narrative Discourse and Historical Representation. Baltimore: Johns Hopkins UP, 1987. Print. 
Young, Robert J. C. “Ideologies of the Postcolonial." Interventions: International Journal of Postcolonial Studies 1.1 (1998): 4-8. Print.

Zuidervaart, Lambert. "Introduction." The Semblance of Subjectivity: Essays in Adorno's Aesthetic Theory. Eds. Tom Huhn and Lambert Zuidervaart. Cambridge, MA: MIT Press, 1997. 1-28. Print. 